\title{
Students'Translation Strategy in Translating Proper Noun
}

\author{
Jema'ah ${ }^{1}$ Roganda Eko Sutra Manullang ${ }^{2}$
}

Universtias Prima Indonesia

$\underline{071296 @ g m a i l . c o m}^{1} \underline{\text { rogandasimanulang@gmail.com }}^{2}$

\begin{abstract}
This review manages the understudies' translation technique in deciphering thing. This review was led by utilizing graphic subjective exploration. This review was done in SMK Sandhy Putra 2 Medan. The subject of this examination were the understudies in SMK sandhy Putra 2 Medan. The examination was led in two days. The main day, the scientist gave test to the understudies. The subsequent day, the scientist directed meeting the understudies. The instruments utilized in this examination were test and meeting. The test given used to know the understudies' translation procedure in deciphering thing while meet led to know the understudies' concern in interpreting thing. In light of the investigation of information, it was found that there were three sorts of translation procedure found, in particular modify, replacement of sound and unique structure.
\end{abstract}

\section{Key words: translation, proper noun}




\section{CHAPTER II \\ INTRODUCTION}

These days, for the vast majority, data has turned into a need. Hence, data trades through worldwide correspondence are required among individuals all over the planet by utilizing a specific language that can be perceived by individuals from various nations. English is a global language that is utilized to move data. Consequently, English is utilized in many broad communications as the fundamental wellspring of numerous sorts of data. In any case, there are as yet many individuals on the planet that don't dominate English. It will be hard for them to retain the data in English. All things considered, translation is expected to move data from unknown dialects and to make correspondence among individuals with different dialects conceivable.

The action of deciphering is extremely convoluted, on the grounds that there are a few angles which must be considered by an interpreter. Translation requires an etymological information, all the more explicitly syntactic information and adaptability in semantic examination. The interpreter ought to likewise see a few perspectives which are connected with the translation cycle, in light of the fact that the course of translation is more than deciphering many sentences, however the significance should be precise. Consequently, the interpreter assumes a significant part in moving the data.

Since every language has its own standard or design in expressing thoughts, an interpreter must have the option to track down the appropriate techniques in deciphering a specific text. Each sort of text needs proper technique connected with translation hypothesis, and it likewise has its own style and hardships. Other than the entire messages of the source message must be passed on normally and precisely, the interpreter ought to likewise think about the style. To get an translation that isn't similar to an translation work, an interpreter needs a few endeavors to move the data from the source language into the objective language.

This condition additionally happened to the understudies when they learnt translation. The author had this experience when she did her showing practice at school. A few understudies' actually have issue in translation. This is the justification for why the author needs to direct the exploration. The author needs to propose a few techniques which can help te understudies in deciphering sentence.

To help the examination, the author took some past research. To begin with, Sabzalipour and Phiskar (2015). Translation of appropriate names are testing assignment of an interpreter as there are not anyconsensus among translation researchers about their translatability or untranslatability. To handle the issue, the current review endeavored to apply Fernandes (2006) and Farahzad's (1995) model of deciphering methodologies of formal people, places or things in kids' writing from English into Persian. To lead this review as per the translation methodologies of propernames, the information (appropriate names) were removed from Harry Potter and the Half-Blood Prince and afterward investigated dependent on these procedures. The consequences of thepresent research showed that the interpreter has applied literal translation technique, proposed by Farahzad more than other translation procedures $(62.37 \%$ ) and furthermore all of Fernandes (2006) systems were utilized by the interpreter with the exception of record, rendering and customariness.

Second Shirindazeh and Mahadi (2014). Formal people, places or things are respected really basic that they may be underestimated in translation investigations. Some might accept that they ought not be interpreted in communicating source texts to target texts. In any case, it isn't true; assuming one glances at present translations, he will see that various techniques may be applied for deciphering formal people, places or things. They may regularly be risky in translation particularly over the span of version between various societies. In this manner, they merit investigating. The current review plans to research the procedures that have been utilized in delivering formal people, places or things 
by Pazargadi (2003) in his English translation of Hafez's verses. For this object, Vermes' (2003) model of translation techniques for delivering formal people, places or things has been adjusted by the specialists in the review. It has been uncovered that the interpreter has utilized the transaction system most ideally for delivering formal people, places or things of Hafez's verses into English.

In view of the clarification over, the researcher would like to direct an exploration entitled Students'Translation Strategy in Translating Proper Noun. 


\section{CHAPTER II REVIEW OF LITERATURE}

\subsection{Theoretical Framework}

\subsubsection{Translation}

Translation has been characterized in numerous ways by various journalists in the field, contingent upon how they view language and translation. Translation is a system which leads from a composed source language text to an ideally comparable objective language text and requires the syntactic, semantic, elaborate and message practical cognizance by the interpreter of the first message. Deciphering comprises in the replicating in the receptor language the nearest normal likeness the source language message, initially as far as which means and furthermore as far as style. The two definitions above infer that translation includes two dialects: the source language (SL) and the objective or receptor language (TL or RL), and that a demonstration of deciphering is a demonstration of replicating the importance of the SL text into that of the TL text.

Cook (1992: 20) expresses that translation might be characterized as the substitution of literary material in one language (SL) by identical text based material in another dialect (TL). Comparable definition is likewise referenced by Larson (1984: 3). He says that translation comprises of deciphering the significance of the source language into the receptor language. This is finished by going from the type of the principal language to the type of a second language via semantic construction. It is meaning which is being moved and should be held steady. Just the structure changes.

From the ideas above it very well may be inferred that deciphering incorporates the demonstration of moving message from the source message to the objective message. The point of translation is to track down the same significance of the source language articulation in the objective language Consequently, which means is significant in translation and it should be held constant. Furthermore, making an translation of an abstract work into another dialect is making another scholarly work in another dialect. An translation novel is a clever that contains distinctive language from the first text however conveying the soul of the first text. It additionally stirs the equivalent react to the perusers between the two dialects.

\subsubsection{Types of Translation}

Newmark (1988: 21-25) makes classes of translation as far as degree, levels, and positions. In light of the degree, he groups translation into full and halfway

translation. On the degrees of translation, there are all out and confined translation andon the positions there are rank bound and unbounded translation. In full translation, the whole text is submitted to the translation interaction, that is, all aspects of the source language text is supplanted by the objective language text material. In halfway translation, a few pieces of the source language text are left untranslated. They are basically moved to the objective language text. All out translation implies the substitution of SL punctuation and lexis by identical TL language and lexis with considerable substitution of SL phonology or graphology by non comparable TL phonology or graphology. While confined translation implies the substitution of SL text based material by identical TL text based at just one level, that is translation performed distinctly at the phonological or at graphological level, or at just one of the two degrees of sentence structure and lexis. Rank-bound translation is translation in which the determination of TL reciprocals is intentionally restricted to one position or a couple of positions in the order of linguistic units, typically at word or morpheme rank, that is, setting up wordto-word or morpheme-to-morpheme proportionality. Conversely, with this, typical all out translation where equivalences shift openly out of control the position scale is called unbounded translation.

As per Larson (1984: 15) translation is grouped into two principle types, specifically structure based and which means based translation. Structure based translation endeavors to follow the type of Source Language and is known as exacting translation, while which means based translation bends over backward to impart the importance of the SL text in the regular types of the receptor language. Such translation is called informal translation. Larson (1984: 16) says that colloquial translations utilize the normal types of the receptor language both in the syntactic developments and in the decisions of lexical things. A genuinely colloquial translation doesn't seem like an translation. It seems like it was 
composed initially in the receptor language. Hence, a decent interpreter will attempt to decipher informally.

By and by, notwithstanding, it is difficult to reliably decipher colloquially or in a real sense. These translations are regularly a combination of strict and informal types of language. Translation then, at that point, falls on a continuum from extremely exacting, to strict, to adjusted strict, to approach informal, to colloquial, and may fall, much inclining further toward the unduly free.The interpreter's objective ought to be an informal translation.

Newmark (1988: 46) states that informal translation repeats the message of the first however will in general contort subtleties of significance by favoring expressions and saying where these don't exist in the first. He will realize he is effective on the off chance that the receptor language perusers don't perceive his work as an translation by any means, yet essentially as a message written in the receptor language for their data and happiness.

\subsubsection{Translation Process}

According to Larson (1984: 3) while interpreting a text, the interpreter's objective is an informal translation which bends over backward to convey their importance of the SL text into the normal types of the receptor language. Besides, he expresses that translation is worried about an investigation of the vocabulary, syntactic design, correspondence circumstance, and social setting of the SL text, which is broke down to decide its importance. The found significance is then recommunicated or reproduced utilizing the dictionary and syntactic construction which are proper in the receptor language and its social setting. The accompanying outline is introduced by Larson as the translation cycle.

Nida and Taber (1982: 33) recognize translation process into three phases:

(1) examination, in which the surface construction is dissected as far as (a) the syntactic connections and (b) the significance of the words and blends of words, (2) move, in which the investigated material is moved in the psyche of the

interpreter from language A to language B, and (3) rebuilding, in which the moved material is rebuilt to make the last message completely $\mathrm{OK}$ in the receptor language. The translation interaction can be outlined in the accompanying graph.

\subsubsection{Form and Meaning in Translation}

Larson (1984: 3) expresses that translation is essentially a difference in structure. These structures are alluded to as the surface design of a language. It is the primary piece of language which is really found on paper or heard in discourse. Bread cook (1992: 24) says that the type of the source language in translation is supplanted by the same lexical thing (type) of the receptor language. Nonetheless, there is regularly no comparable in the objective language for a specific structure in the source text. As per Larson (1984: 3), translation is finished by going from the type of the principal language to the type of second language via semantic design.

At the point when an interpreter makes an translation, it implies that the person moves importance of source text. What is important to consider is that the significance should be kept up with continually or, as such, when the difference in structure happens, the significance should be kept up with. It is the trait of a language that a similar importance part will happen in a few surface design lexical things (structures).

In the translation cycle, the main thing to do is comprehend the absolute importance of the source text. There are three kinds of "signifying" that still up in the air in the investigation of significance of the source text (Nida and Taber, 1982: 34), in particular (1) syntactic importance, (2) referential importance, and (3) demonstrative importance. In linguistic importance, when one considers meaning, it is unavoidably as far as words or phrases. By and large punctuation is underestimated since it is by all accounts just a bunch of self-assertive principles about game plan, decides that should be followed to see, however not decides themselves that appear to have any importance. Referential importance alludes to words as images which allude to objects, occasion, edited compositions, and relations. Suggestive importance alludes to how the clients of the language respond, regardless of whether decidedly or contrarily, to the words and their blend. 
Translation has been proceeded as a cycle which starts with the source text, then, at that point, the significance of the text is broke down, found, moved, and reexpressed in the receptor language. In genuine practice, be that as it may, the interpreter moves back and advance from the source text to the receptor text. Some of the time the person will investigate the source text to observe the importance, then, at that point, rebuild this significance in the receptor language, and move back to take a gander at the source text.

In translation, the interpreters should know the sorts of implications. By realizing what which means they should deliver, the messages of the source message can be moved well. Then, at that point, the all around moved significance will make more clear for the perusers.

\subsubsection{Startegies in Translating Proper Noun}

There are diverse translation procedures in deciphering appropriate names acquainted by specialists and etymologists with general society. Translators must ought to be comfortable with the way of life of both objective and source language; normally social mindfulness might actually prompt the most dependable translation of a legitimate name. And furthermore, there are subsequently a lot of strategies of deciphering a legitimate name, yet it is fitting assuming interpreters should make reference to the first name in the commentaries, to direct specialists or perusers comprehend the intricacies of deciphering an appropriate name.

Vermes (2001)in Sabzalipour and Phiskar ( 2015) disclosed that as per Tarnoczi, the interpreter might pick literal translation of names in a text. He recognized the literal translations of letters and of phonetic qualities, recommending that between various scripts just the previous ought to be applied and that the last option is additionally best kept away from between dialects utilizing a similar content. He focused on the significance of being predictable all through an translation. $\mathrm{He}$ further called attention to that albeit individual names can hypothetically be interpreted, the most suitable arrangement is to reflect them into the TT, that is, protect them in the first structure. This matter likewise applies to geological names and titles of masterpieces. What's more Solteszdistinguished three fundamental kinds of appropriate names concerning their importance.

a. Sign names, similar to 'John', 'Duna', and so on which have no significance in the manner that

normal name does and are non-graphic, non-indicative and unmotivated.

b. Word names that she describes them as propelled, suggestive, and generally unmistakable. For example, 'Kreml', 'Lanchid', 'Mont Blac' that with taking a break large numbers of these names have lost their graphic person and have become hazy in this regard.

c. Names which are mixes of sign names and components from the normal word classes.

These components might be modifiers, postfixes or most often, words naming a higherlevel calculated classification.

At last, she offers the accompanying translation systems for the various sorts of names:

For the main kind, she clarified that these names might be subbed by a comparing name in the unknown dialect or left unaltered. For the second and

third sort, she brought up that these names might be somewhat or completely interpreted or substituted."(Vermes, 2003) in Sabzalipour and Phiskar ( 2015).

Newmark (1988) recognized three sorts of appropriate names:

1) People's names

2) Names of articles

3) Geographical terms

As indicated by him, individuals' names are regularly moved with the understanding that these have no undertones in the text, by which their identity is protected. In some remarkable cases, nonetheless, an individual name might be interpreted, for example, rulers, popes, holy people or names which have undertones in innovative writing. Also different names are naturalized. I. e. changed over to typical objective language spelling or articulation which as per different researchers is literal translation. Furthermore names of items, including brand names, brands and decencies are typically moved. 
Based on the explanation above, it can be concluded that there are three three techniques for the translators during process of translating proper noun.

1. First, translators can transfer them, that is, carry over the name into the receptor language in the original form.

Example:

Tape in Indonesia will be translated to Tape in English.

2. Second, they can translate the name in the ordinary sense of the term or substitution of sounds.

Example:

Jesus in English will be translated to Jahoba in Batak language

3. Third, they can alter or modify the name which means substituting the name by a receptor language expression which is not in direct correspondence with it.

Belimbing in Indonesia will be transalated to Starfruit in English.

\subsubsection{Noun}

Nouns are words that stand for people, places and things (Phyllis:2010). In addittion. The word 'noun' comes from Latin nomen meaning name'(Dykes:2007). A noun is the name of a thing. Everything that exists has a name, whether you can see it or not. A blind person cannot see something, but that does not mean that it isn't there! It may only exist in our minds, like hope, beauty or calories. People and places are easy enough to recognize: Philip, Marcel, Pittsburgh, the Rosebowl, Radio City Music Hall - and we could go on forever. Things are easy, too: table, pens, candy, and TV are just a few. More diffi cult to recognize are the words we call abstract nouns. These are ideas or qualities such as honor, love, loyalty, and determination.A good rule of thumb for recognizing a noun is this: If you can put $a$, an, or the in front of the word and it still makes sense, it's a noun.

\subsubsection{Types of Noun}

Thera are four types of noun. They are: common noun, collective noun, abstract noun.

\subsubsection{Common Noun}

These are names of everyday things that we can see, hear or touch.

For example:

table, banana, volcano, song

We can put the word 'the' in front of them and make sense, as in:

the rope, the poison

\subsubsection{Collective Noun}

These are names for groups of things, animals or people, which go together, or have something in common.

For example:

A number of people in a group singing is a choir.

A number of cows in a group is a herd.

Note here that if the group word is singular then the verb following must also be singular.

For example:

Correct - The choir was rehearsing in the chapel.

Incorrect - The choir were rehearsing in the chapel.

There may, of course, be more than one group. In which case the

verb will be plural.

The cho irs were competing in the final.

\subsubsection{Abstract Noun}

Abstract nouns form what can be the most difficult group to understand, as they represent ideas, and have no physical substance that you can see or touch. The idea may be of quality,

For example: beauty, greed, intelligence 
or the idea may be a state that is felt or suffered, for example: joy, misery, neglect.

It may be the act of something,

for example: duty, aggression.

It may even be an event or happening,

for example: conversation, pause.

\subsubsection{Proper Noun}

The word 'proper' comes from the French word propre meaning one's own, i.e. belonging to a particular person or thing. Proper nouns are the special names that we give to people, places and particular things like the days of the week, months of the year, or even the titles of books or TV shows.

For example:

Jason, Town Hall, China, French, The Wishing Chair Because they are special and individual names, they start with a capital letter and, apart from people, most of these things have only one proper name. 


\section{CHAPTER III \\ DISCUSSION AND FINDINGS}

In order to collect the data for this research, the writer applied these following procedures:

1. The writer gave the test to the students

2. The writer gave a short explanation of how to do the test.

3. The students did the test for 45 minutes.

4. The writer did the students'answer sheet.

The data of this research were the students' translation strategies in translating proper noun.

The data collected by the writer were categorized by the following translation procedures namely:

1. Alter/modify

2. Substitution of Sound

3. Original Form

Below is the categorization of students' translation strategies. 


\begin{tabular}{|c|c|c|c|}
\hline NO & $\begin{array}{l}\text { STUDENT'S } \\
\text { INITIAL }\end{array}$ & TRANSLATION STRATEGY & \\
\hline 1 & $\mathrm{AM}$ & 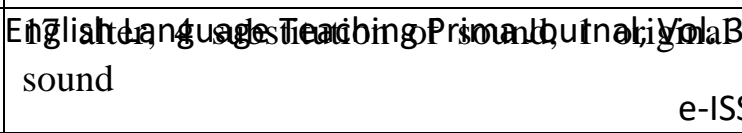 & SN: 2686-1526 \\
\hline 2 & ANS & 16 Alter, 3 substitution and 1 original sound & \\
\hline 3 & BSN & $\begin{array}{l}17 \text { Alter, } 2 \text { substitution of sound and } 1 \\
\text { original sound }\end{array}$ & \\
\hline 4 & CAA & 16 Alter, 4 substitution of sound & \\
\hline 5 & DS & $\begin{array}{l}16 \text { Alter, } 3 \text { substitution of sound and } 1 \\
\text { original sound }\end{array}$ & \\
\hline 6 & DAP & $\begin{array}{l}15 \text { Alter, } 4 \text { substitution of sound and } 1 \\
\text { original sound }\end{array}$ & \\
\hline 7 & FF & $\begin{array}{l}16 \text { Alter, } 4 \text { substitution of sound and } 2 \\
\text { original sound }\end{array}$ & \\
\hline 8 & GRS & $\begin{array}{l}15 \text { Alter, } 4 \text { substitution of sound and } 1 \\
\text { original sound }\end{array}$ & \\
\hline 9 & HS & $\begin{array}{l}12 \text { Alter, } 4 \text { substitution of sound and } 2 \\
\text { original sound }\end{array}$ & \\
\hline 10 & JQ & $\begin{array}{l}14 \text { Alter, } 4 \text { substitution of sound and } 2 \\
\text { original sound }\end{array}$ & \\
\hline 11 & $\mathrm{NHH}$ & $\begin{array}{l}15 \text { Alter, } 4 \text { substitution of sound and } 1 \\
\text { original sound }\end{array}$ & \\
\hline 12 & MP & $\begin{array}{l}15 \text { Alter, } 4 \text { substitution of sound and } 1 \\
\text { original sound }\end{array}$ & \\
\hline 13 & MLP & $\begin{array}{l}16 \text { Alter, } 2 \text { substitution of sound and } 1 \\
\text { original sound }\end{array}$ & \\
\hline 14 & MFH & $\begin{array}{l}16 \text { Alter, } 3 \text { substitution of sound and } 1 \\
\text { original sound }\end{array}$ & \\
\hline 15 & PJN & $\begin{array}{l}14 \text { Alter, } 4 \text { substitution of sound and } 2 \\
\text { original sound }\end{array}$ & \\
\hline 16 & RGS & $\begin{array}{l}14 \text { Alter, } 2 \text { substitution of sound and } 4 \\
\text { original sound }\end{array}$ & \\
\hline 17 & RRA & $\begin{array}{l}15 \text { Alter, } 4 \text { substitution of sound and } 1 \\
\text { original sound }\end{array}$ & \\
\hline 18 & RAP & $\begin{array}{l}16 \text { Alter, } 3 \text { substitution of sound and } 1 \\
\text { original sound }\end{array}$ & \\
\hline 19 & TRJ & $\begin{array}{l}18 \text { Alter, } 1 \text { substitution of sound and } 1 \\
\text { original sound }\end{array}$ & \\
\hline 20 & RV & $\begin{array}{l}17 \text { Alter, } 2 \text { substitution of sound and } 1 \\
\text { original sound }\end{array}$ & \\
\hline 21 & SA & $\begin{array}{l}16 \text { Alter, } 3 \text { substitution of sound and } 1 \\
\text { original sound }\end{array}$ & \\
\hline
\end{tabular}




\begin{tabular}{|l|l|l|}
\hline 22 & UCA & $\begin{array}{l}14 \text { Alter, 4 substitution of sound and 2 } \\
\text { original sound }\end{array}$ \\
\hline 23 & TS & $\begin{array}{l}16 \text { Alter, 3 substitution of sound and 1 } \\
\text { original sound }\end{array}$ \\
\hline 24 & YA & $\begin{array}{l}15 \text { Alter, 4 substitution of sound and 1 } \\
\text { original sound }\end{array}$ \\
\hline 25 & YSH & $\begin{array}{l}14 \text { Alter, 4 substitution of sound and 2 } \\
\text { original sound }\end{array}$ \\
\hline
\end{tabular}

Table 4.2. The Categorization of Students' Translation Strategies

From the data above, it can be concluded that:

1. The students used three translation strategies in translating pronoun, they are:

1. Alter

2. Substitution of Sound

3. Original sound

2. From the data above, it also can be concluded that the most dominant translation strategy used by the students in translating proper noun is alter strategy.

After deriving the students' translation strategies, the writer then asked the students about their difficulties in translating proper noun. From the interview, the writer derived some reasons. They are:

1. Their lack of vocabulary

2. Lack of reading

3. Not having knowledge of what they translate 


\section{REFERENCES}

Ary et al.2010. Introduction to Research in Education. New York. Prentice Hall.

Baker, M. 1992. In Other Words. London: Routledge.

Dykes, Barbara.2007. Grammar for Everyone. Vicoria. Acer Press.

Dawson Cathrine. 2002. Practical research Method. Oxford How to books, ltd.

Fluche, Gleen and davidson. Language Testing and Assesment. An Advanced Resource Book. London. Routledge.

Frankael, jack.R and wallen, Norman E. 2009. How to Design and Evaluate Research in Education. Seventh edition. Boston. McGraw Hill Higher Education.

Larson.Mildred. 1984. Meaning Based Translation. Boston: University Press of America,Inc.

Mozghan, Sabzalipour, \& Phiskar,Kian. 2015. Translation Strategies of Proper Noun in Childfren's Literature. Journal of Applied Linguistics and Language Research

Volume 2, Issue 6, 2015, pp. 73-79

Newmark, P., 1988. A Textbook of Translation. New York: Prentice Hall.

Phyllis, Dutwin. 2010. English Grammar Demistified. New York. Mc Graw Hill.

Shirinzadeh, Seyed.A. \& Mahadi Tengku Sepora. 2014. Translating Proper Noun: A Case Study of English Translation of Hafez' Lyrics. English Language Teaching; Vol. 7, No. 7; 2014. 